committee of aldermen. From St. Louis comes a most interesting description of a central traffic-parkway, designed to pass the public buildings and the union railroad station and to facilitate traffic intercourse between the business and residence parts of town, the while it redeems a blighted district. This report, which is handsomely issued, bears the imprint of the city's official plan commission. ${ }^{14}$ The reports which are issued from New London ${ }^{15}$ and Council Bluffs ${ }^{16}$ outline park systems. They were made by town planners at the request of the park commissions.

In closing, a third type of city planning publication demands recognition, for the light it may throw on recent American practice. This is the annual report of official plan commissions such as those of Hartford and of Pittsburgh. There are few of these yet, and of the few, first reports are only beginning to appear. But they are destined to become a growingly important branch of American town planning literature, and doubtless we shall soon be turning to them for the most accurate record of actual town planning progress in the United States. From that point of view, the report from Pittsburgh, ${ }^{17}$ taking up briefly but clearly the status of the various projects that are being locally considered or developed, is a model in arrangement. When many cities and towns are annually issuing such reports, upon a like official authority, town planning will have graduated into town building.

$$
\text { Rochester, N.Y. Charles Mulford Robinson, }
$$

\title{
PITTSBURGH'S HUMP
}

$\infty$ INCE the days of the early history of Pittsburgh in the middle of the seventeenth century, the eminence known as Grants hill, now more often referred to as the "hump," has proved a barrier to both traffic and the extension of the business district. The name Grants hill was given this elevation on account of it being the site of the battle between the English under command of Colonel James Grant and the French and Indians on the morning of September 14, 1785. It was on this occasion that history first records the fact that this hill

14 St. Louis Central Traffic-Parkway Recommended by The City Plan Commission. July, 1912.

w5 General Plan of a Park and Playground System for New London, Conn., by John Nolen. 1913.

${ }^{16}$ Report on a Park System for Council Bluffs, Ia. Made to the Board of Park Commissioners by Charles Mulford Robinson. 1913.

${ }^{17}$ Annual Report of the Department of City Planning, Pittsburgh, Pa., for the fiscal year ending January $31,1913$. 


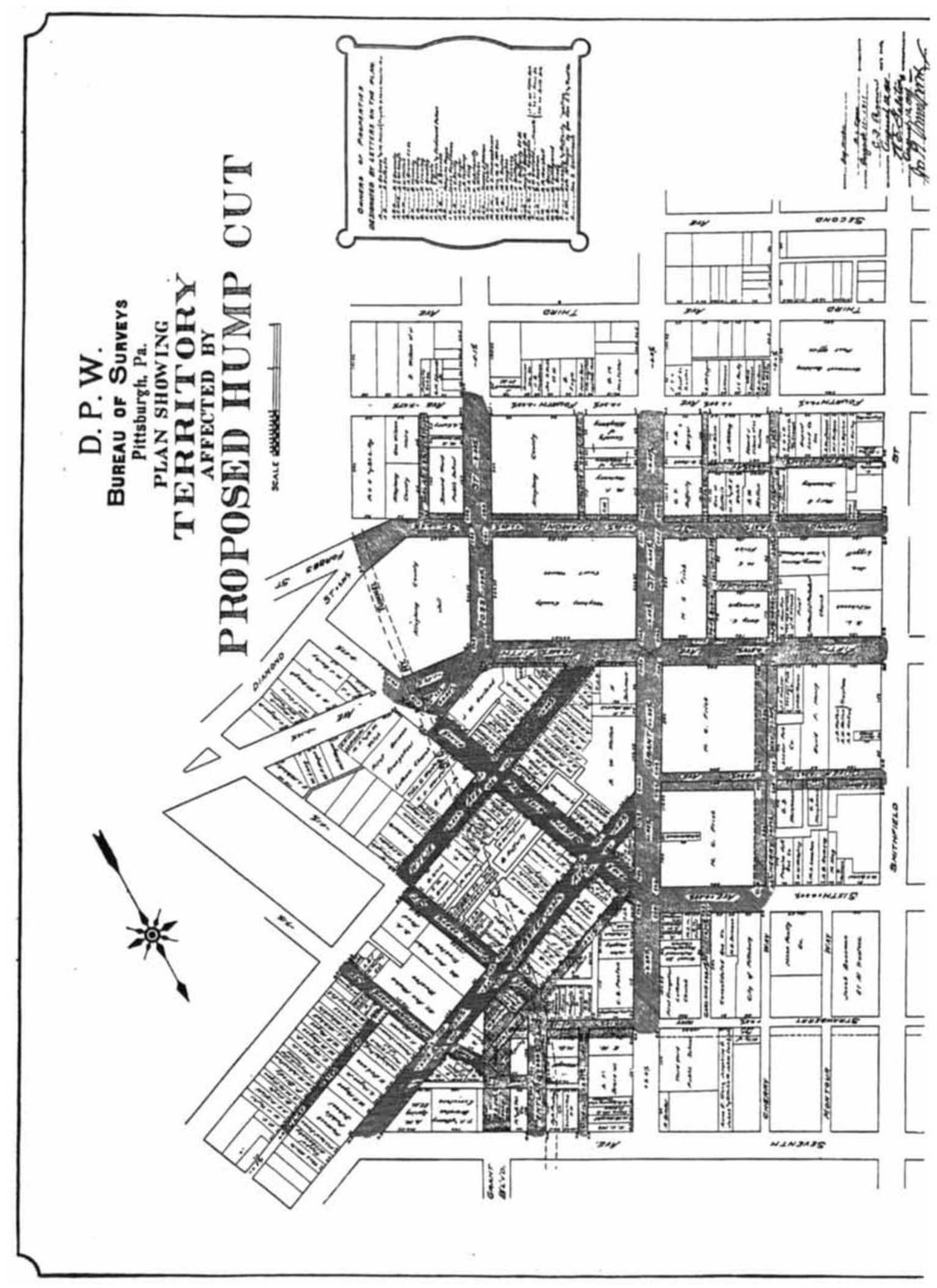


proved an obstruction to traffic. The hill then covered with underbrush and briars and gashed with ravines and gulleys proved a decided barrier to the routed English.

In "The Town of Pittsburgh," laid out by George Woods, surveyor, by order of Tench Francis, Esq., attorney for John Penn, Junior, and John Penn in 17.84, Grants hill formed the eastern boundary, the town being in the form of a triangle with the Allegheny and the Monongahela rivers for the other sides.

The elevation of Grant street at this time is unknown, but the block between Fifth avenue and Diamond alley was sufficiently high to be chosen as the site for a distributing reservoir, the elevation of the basin being recorded as 116 feet above the Allegheny river, which is practically the zero of the present city datum. This basin was used until about 1844 when it was replaced by a new one erected on the top of Stone Quarry hill.

Soon after the incorporation of Pittsburgh, the "hump" began to receive notice as an obstruction to traffic with the surrounding territory and as early as 1836, councils passed an ordinance re-establishing the grade of Grant street and Fifth avenue. This ordinance, fixing the new grade at the intersection of these streets, stated that the elevation "shall be reduced ten feet below the present surface and the permanent grade thereof shall be fixed at ten feet below the top of the middle front door sill of Saint Paul's Church." The same ordinance provided for the raising of the intersection of Fifth avenue and Smithfield street four feet. The maximum gradient of Fifth avenue over the hump was therefore reduced about two and eight tenths per cent.

It is difficult to give the exact date when this cut was made, but that the work was started soon after the enactment of the ordinance fixing the grade is generally accepted.

With the rapid growth and expansion of the city and the resulting increase of traffic to and from the "point," the reduced grades were still found to be a drawback to the section of the city immediately beyond Grants bill. We therefore find that in November, 1847, councils provided for the removing a second slice from the hump. This time the ordinance re-establishing the grade of Fifth avenue provided "that Fifth street shall have an ascending grade from a point opposite the line between lots 381 and 382 to two feet above the upper curb of Smithfield street, at its present grade, and that Fifth avenue shall rise from the grade of Smithfield street to Grant street seven feet below the present grade thereof."

As the years passed and Pittsburgh continued to expand and develop until she became the leading iron center of the country, it was realized that still more of the hump must come off. The economical depth of 
cut to be made and the means of financing the proposition were discussed from time to time. It was, however, not until more than sixty years after the second slice had been removed that the administration and council decided the work of reducing the grades over this barrier for the third time must be done. In November, 1911, a councilmanic bond issue was voted and likewise the necessary grade and improvement ordinances passed.

The contract was awarded April 5, 1912, to Booth \& Flinn calling for the completion of the improvement prior to January 1, 1914, the estimated cost for regrading, recurbing, repaving and relaying the sewers and water lines being $\$ 690,000$.

In addition to the regrading of the streets within the hump district, it became apparent that, with the present congested conditions of the thoroughfares in this district, the improvement would be minimized to a large degree if Grant boulevard was not extended to a connection with the more centralized street system and several other streets and alleys widened to care for the rapidly increasing traffic.

It was consequently decided that, although the expense would be almost unparalleled, several of the more essential changes in the plan of streets of the district should be made simultaneous with this third lowering of the hump. The proposition, therefore, assumed greater magnitude with the authorization for the changes in the widths of six centrally located streets and as a whole was probably one of the most extensive and costly municipal improvements, of like nature, ever undertaken in an old built-up city district in this country.

It must be remembered that all of the blocks affected by the change contained buildings that had to be remodeled at an enormous expense to the owners or removed to make room for the larger and more modern structures that will be erected.

In view of the fact that the property holders are now assured that the grades of the streets are definitely fixed for another half century or more, and with the former objection to the use of this section for an extension to the principal retail district, to which it is contiguous, removed, it is estimated that more than $\$ 20,000,000$ will be spent for new buildings within the next few years. As a matter of fact, at this date, plans are under way for new buildings in excess of $\$ 7,000,000$.

Figure 1 is a map of the affected territory, showing the street extension and widening, the depth of cuts at the various intersections and the new gradients. For the extension of Grant boulevard, the widening of Fifth avenue, Oliver avenue, Diamond street, Strawberry way and Cherry way some of the most valuable properties in the city were appropriated. The entire improvement was completed about the middle of December, substantially as shown, with the exception of the widening of Diamond 
street between Smithfield street and Grant street, which was deferred until some future date.

Table 1 shows a comparison of the old and new grades on the main avenues and streets and Table 2 shows the cost to the city and the abutting property holders for the widening of the thoroughfares named, as fixed by the board of county viewers, together with the estimated cost of the various items included in the general improvement.

TABLE 1

Showing the Old and New Rates of Grades on the Main Streets and Avenueg

\begin{tabular}{|c|c|c|c|c|}
\hline STREET & FROM & то & $\begin{array}{c}\text { OLD } \\
\text { RATE }\end{array}$ & $\begin{array}{l}\text { NEW } \\
\text { RATE }\end{array}$ \\
\hline \multirow[t]{4}{*}{ Fifth svenue } & Smithfield St. & Grant St. & 7.6 & 4.872 \\
\hline & Grant St. & Wylie Ave. & 3.5 & 2.355 \\
\hline & Wylie Ave. & Ross St. & 1.7 & 2.355 \\
\hline & Ross St. & Sixth Ave. & 5.0 & 1.56 \\
\hline \multirow[t]{3}{*}{ Diamond street } & Smithfield St. & Grant St. & 7.0 & 4.87 \\
\hline & Grant St. & Ross St. & 2.6 & 1.50 \\
\hline & Ross St. & Forbes St. & 4.3 & 0.6 \\
\hline Oliver avenue & Smithfield St. & Grant St. & 7.7 & 4.96 \\
\hline \multirow[t]{3}{*}{ Sixth avenue } & Cherry Way & Grant St. & 6.7 & 4.54 \\
\hline & Grant St. & Wylie Ave. & 5.0 & 3.18 \\
\hline & Wylie Ave. & Fifth Ave. & 2.5 & 1.00 \\
\hline \multirow[t]{5}{*}{ Grant street } & Fourth Ave. & Diamond St. & 4.8 & 0.55 \\
\hline & Diamond St. & Fifth Ave. & 2.3 & 0.55 \\
\hline & Fifth Ave. & Oliver Ave. & 2.0 & 1.22 \\
\hline & Oliver Ave. & Sixth Ave. & 4.2 & 1.42 \\
\hline & Sixth Aỵe. & Strawberry Way & 4.2 & 2.29 \\
\hline \multirow[t]{3}{*}{ Webster avenue } & Grant St. & Sixth Ave. & 5.0 & 0.87 \\
\hline & Sixth Ave. & Tunnel St. & 5.0 & 3.5 \\
\hline & Tunnel St. & Seventh Ave. & 2.5 & 3.71 \\
\hline Strawberry Way & Grant St. & Pentland St. & 11.6 & 7.13 \\
\hline
\end{tabular}


TABLE 2

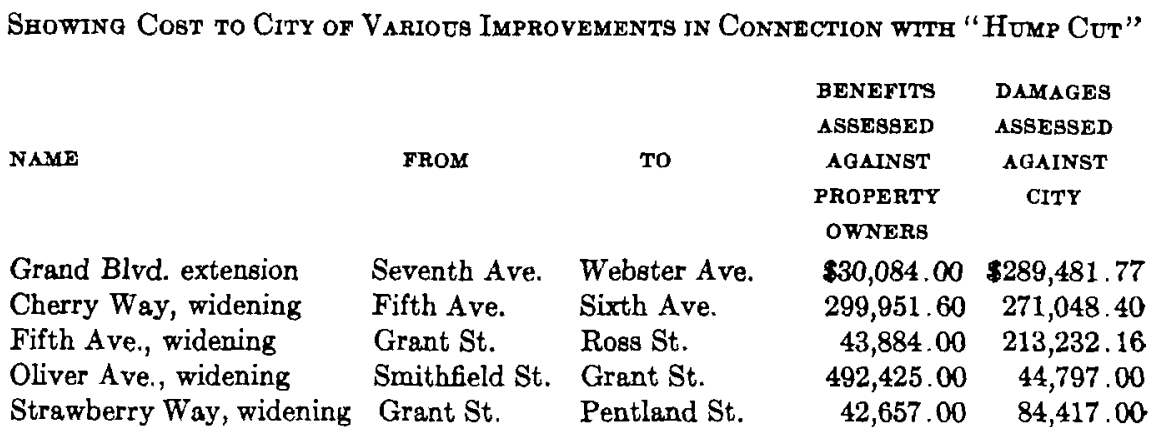

Awards for damages account change in grade alone for properties on which damage waivers were not obtained (estimated)

Expense account adjustment of buildings for which damages were waived by property holders (estimated)

Expense of public service corporation in lowering conduits, relaying railway tracks, etc. (estimated)

Physical work, regrading, repaving, recurbing, relaying sewer, etc. (final estimate)

Relaying water main

Estimated cost of two former Hump Cuts, $\$ 100,000.00$.

With the completion of the project many criticisms as well as words of commendation have been heard regarding the improvement in general. Those having the plans in charge never felt that the ideal condition had even been approached, but they were assured that the results were the best that could be accomplished under the existing conditions. In any municipal improvement of this nature, the nearest approach to a perfect plan that can be considered attainable is always a compromise between the ideal plan and the limit to which the abutting property holders, taken as a unit, can be induced to go, after being convinced that their holdings will be benefited to the extent of the damage, measured by the value of the property before and after the change is made.

In the reduction of the hump, involving an area of approximately thirty-five acres owned by over 180 holders, it is evident that many concessions must be made in order to secure release from all damage due to the change of grade of nearly seventy-five per cent of the area affected. With the completion of the third and greatest hump cut, barring some slight changes that might have been advantageous at different points, it is generally agreed that the improvement was well 
planned and admirably executed. The unsettled conditions existing in this section for more than a score of years is now thoroughly established and with the grades of the streets reduced and fixed, the way is clear for the early completion of the great building projects that have been so long delayed.

The preparation of all plans as well as the supervision of the contract work was done by the department of Public Works, under the direction of Joseph G. Armstrong, director, now mayor of the city.

The alterations consequent upon the cutting of the hump for such large buildings as the Allegheny'County court house and jail, the Frick and Carnegie office buildings and the Kaufmann stores and other large buildings, have been completed. But the repaved streets enclose other squares, which are still covered with old and worthless buildings, that have remained undisturbed for years, in anticipation of this improvement. They now look as though a conflagration had swept over them. We are therefore left to the imagination only for the far-reaching results, which must follow the completion of this great municipal undertaking. But there are signs, which indicate the magnitude of the reconstruction, which is already begun.

The preliminaries having been settled between the municipal authorities and the county commissioners, the architect has planned for a joint structure to include a new city hall and a new county building or annex, on Fourth avenue, Grant and Diamond streets, which together will cost. approximately $\$ 2,500,000$ for the buildings, not including the cost of site, furnishing, or fixtures. These buildings with Henry H. Richardson's masterpiece, the county court house and jail, will form a prominent part of the western side of a great civic center in the hump district.

The William Pitt theatre, which is to be built forthwith at the corner of Oliver avenue and Cherry way at a cost of $\$ 250,000$, will also be on the western side of the hump district.

The latest building project in this district is that of the William Penn hotel, to be built by the Fort Pitt Hotel Company on a site purchased. from H. C. Frick, 130 by 216 feet, bounded by Sixth avenue, Oliver avenue and Cherry way. The site cost $\$ 1,684,800$, or $\$ 60$ per square foot. The hotel building, which will be modern in every particular, will contain 900 rooms and will cost from $\$ 2,000,000$ to $\$ 2,500,000$; with an additional $\$ 750,000$ for furnishing and equipment will make a. total cost of about $\$ 5,000,000$.

These large building projects are precursors of what must soon follow in vindication of the farsightedness, courage and indomitable energy, which carried this formidable undertaking to completion.

$$
\text { C. N. ARthur. }{ }^{1}
$$

${ }^{1}$ Principal Assistant Engineer, Bureau of Engineering, Department of Public Works, Pittsburgh. 